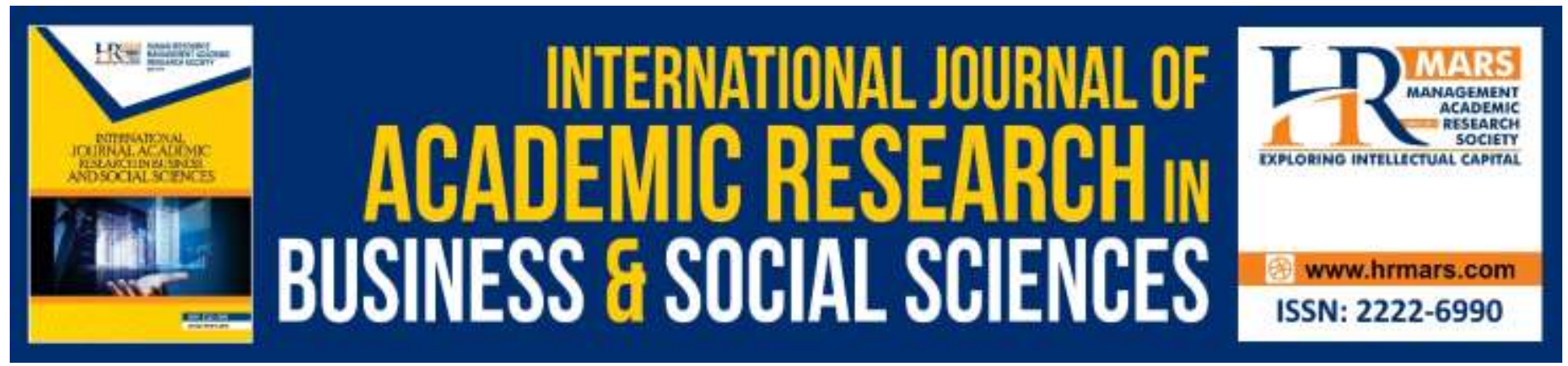

\title{
Effects of Comprehension Monitoring on Academic Performance of Primary School Pupils in Nakuru West Sub- County, Kenya
}

Matunga Hellen Agutu, Paul Gichohi, Bernard Wamalwa

To Link this Article: http://dx.doi.org/10.6007/IJARBSS/v9-i11/6549

DOI: 10.6007/IJARBSS/v9-i11/6549

Received: 17 October 2019, Revised: 29 October 2019, Accepted: 01 November 2019

Published Online: 24 November 2019

In-Text Citation: (Ling et al, 2019)

To Cite this Article: Agutu, M. H., Gichohi, P., Wamalwa, B. (2019). Effects of Comprehension Monitoring on Academic Performance of Primary School Pupils in Nakuru West Sub-County, Kenya. International Journal of Academic Research in Business and Social Sciences, 9(11), 284-312.

Copyright: (C) 2019 The Author(s)

Published by Human Resource Management Academic Research Society (www.hrmars.com)

This article is published under the Creative Commons Attribution (CC BY 4.0) license. Anyone may reproduce, distribute, translate and create derivative works of this article (for both commercial and non-commercial purposes), subject to full attribution to the original publication and authors. The full terms of this license may be seen at: http://creativecommons.org/licences/by/4.0/legalcode

Vol. 9, No. 11, 2019, Pg. 284 - 312

Full Terms \& Conditions of access and use can be found at http://hrmars.com/index.php/pages/detail/publication-ethics 


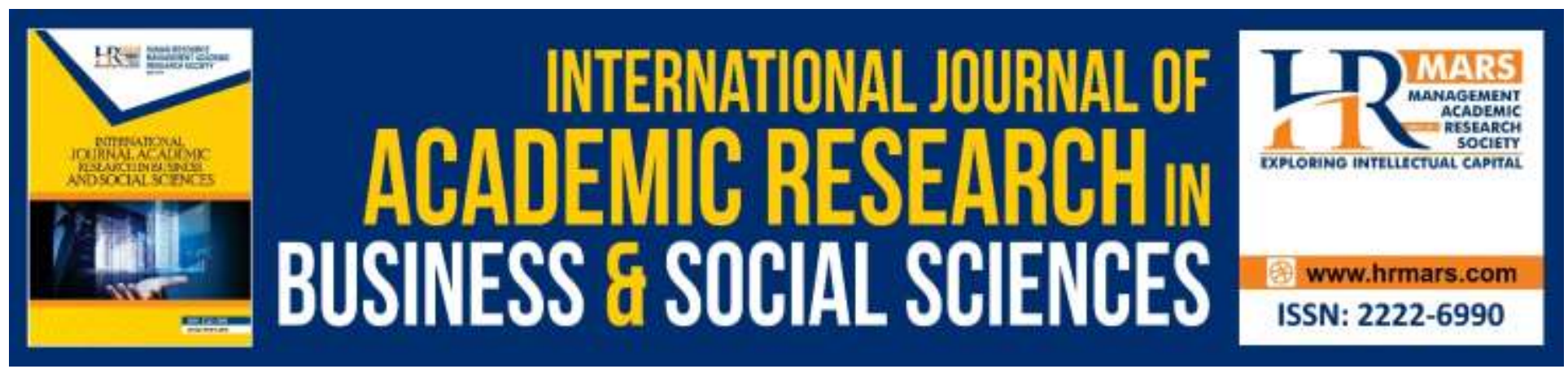

\title{
Effects of Comprehension Monitoring on Academic Performance of Primary School Pupils in Nakuru West Sub-County, Kenya
}

\author{
Matunga Hellen Agutu \\ MEd Student, Kenya Methodist University \\ Dr. Paul Gichohi, Dr. Bernard Wamalwa \\ Lecturer, Kenya Methodist University
}

\begin{abstract}
Academic performance has remained elusive as different cohorts of learners perform differently in national examinations. However, previous studies on academic performance of pupils have explored the question from an environmental perspective, where little attention has been given to the pupil's intrinsic factors such as reading difficulties and successes of respective intervention measures. Interventions on reading difficulties being experienced by learners have been sought, however, the persistence of the problem leads to questions over the efficacy of the interventions. This study set out to find out the effects of comprehension monitoring on academic performance of primary school pupils in Nakuru West Sub-County, Kenya. It was guided by the Cognitive Model of Reading Comprehension. Both descriptive survey and experimental research designs were used. The target population comprised of 12 public primary schools in the area of study from which 342 language teachers and 1133 pupils whom were theorized to have reading difficulties were sampled. A sample size of 160 respondents was selected using both purposive and stratified random sampling for teachers and pupils respectively. Data was collected using a well-structured questionnaire, an observation schedule and through administering a reading test. Data was analyzed with the aid of the Statistical Package for Social Science (SPSS) version 21.0. Descriptive statistics involving means, modes and standard deviations, and inferential statistical methods involving Pearson's Product Moment correlation and ANOVA, were used to analyze data. The results from the tests and the observation schedule were analyzed using content analysis and integrated during interpretations, discussion and conclusion. The study found that comprehension monitoring had a positive and significant effects on academic performance of pupils with reading difficulties in the area. Results from the reading test experiment showed that learners with reading difficulties
\end{abstract}


who had received interventions (Group B) performed significantly better than their counterparts who had not received the interventions (Group A). Hence, the study concluded that the comprehension monitoring as a reading difficulties intervention had the potential of improving academic performance of the learners if well emphasized. Therefore, the study recommended that teachers should introduce regular comprehension tests to monitor the students reading abilities.

Keywords: Academic Performance, Comprehension Monitoring, Interventions, Reading Difficulties

\section{Introduction}

Basic education is both a necessity and a fundamental human right worldwide. Subsequently, the goal of achieving basic education for all has been on the international agenda and has been the overarching theme of global education initiatives such as World Declaration on Education for All (EFA) in Jomtien, Thailand in 1990, the Millennium Declaration and the Dakar Framework for Action (Kinyanjui, 2009). Among other issues, the Dakar Framework urged countries to pursue 'improvement in learning achievements' such that the agreed percentage of an appropriate age cohort attains or surpasses a defined level of necessary learning achievement (UNESCO, 2014; USAID, 2007). The Framework underscored the need for academic performance as a means of educational advancement for learners.

Academic performance has, however, remained an elusive as different cohorts of learners perform differently. Determinants of pupils' performance have been the subject of ongoing debate among the educators, academicians and policy makers. It has formed the subject of several studies worldwide over the years such as the early work of Siegfried and Fels (1979 as cited in Onkoba, 2014) among others that sought to examine this issue. Their findings point out to hard work on the pupils, previous schooling, parent's education, family income and selfmotivation as factors that have significant effects on the pupil's general academic performance. However, most of these studies have explored the academic performance question from an environmental perspective, where the majority adopted motivational or interventionist in the approach. Little attention has been paid to the pupil's intrinsic factors such as reading difficulties (RD) despite the fact that Siegfried and Fels (1979 as cited in Onkoba, 2014) had pointed out that the pupil's aptitude is the most important determinant in his or her learning outcomes.

The ability to read is an essential skill for students to master because; information is mostly presented in text throughout the world. Educational systems also rely more heavily upon text as students reach higher grade levels (Karanja, 2015). According to Tankersley (2003), reading is a complex process comprising several processes and interlocking skills. Anderson (2010) views reading as a mental process of decoding which engages the reader's mind and enables him to derive meaning from text. As such, reading can be explained as the combination of textual information with the information the reader brings to the text that results in comprehension of the text. Therefore, reading is not just about the symbols and words but also speaking and thinking (Onkoba, 2014). It however discouraging to note that many children still complete schooling without achieving more than basic literacy due to reading difficulties (Murnane, 2007). 
Studies such as Richardson and Lyytinen (2014) and Lyytinen and Erskine (2016) show that almost 80 per cent of children with learning disabilities have primary educational problem in the area of reading. The reading problems of all these students have a substantial impact on their ability to master other subjects in school and ultimately affect their performance.

Reading difficulty is defined from a normative perspective, that is, how a child performs in reading compared with peers or educational expectations (Fletcher, Lyon, Fuchs \& Barnes, 2007). A reading disability is a condition in which a sufferer displays difficulty reading. Examples of reading disabilities include: Developmental Dyslexia, Alexia, that is, acquired dyslexia, and Hyperlexia where word-reading ability is well above normal for age and IQ (Ferrer et al., 2010). Typical reading difficulties of adolescents with mild disabilities include problems with vocabulary, word recognition, reading comprehension and reading rate. Children and adolescents who are not proficient with the form, content and function of language have reading difficulties. Form in reading difficulties relates to phonologic, morphologic and syntactic skills. Content, however, refers to semantic, or vocabulary and the relationship among words while function means a student's ability to use a language for pragmatic social purposes (Lerner, 2000).

Several common problems experienced by some students who suffer from reading difficulties have been cited in previous studies such as Jacobs (2007); Murnane (2007); and McLaughlin et al. (2014). These include; omitting letters, syllables or words; inserting extra letters, words or sounds; substituting words that look or sound similar; mispronouncing words; reversing word or syllables; transposing letters or words; and repeating words or using improper inflection during oral reading. Further, the effects of reading difficulties on academic performance have been documented worldwide. For example, a study by Cimmiyotti (2013) in the United States found a correlation between reading and mathematics performance at the early elementary level when including grades two through five. The correlation also appeared to grow in strength at higher grade levels. A study conducted in Hungary by Gósy, Huntley, Gyarmathy and Beke (2018) on dichotic listening and sentence repetition performance in children with reading difficulties found that children with reading difficulties manifested significantly poorer performance in relation to both tasks. In Japan, a study by Yamashita and Hayashi (2014) revealed that the scholastic selfevaluation scores of pupils with RD group were significantly lower than that of the non-RD group. Speed in reading single sounds and single words, and the number of reading errors in reading single sounds had significant negative correlations with scholastic self-evaluation scores.

\section{Statement of the Problem}

UNESCO (2014) estimated that of the world's 650 million primary school age children, and out of these at least 250 million were not learning the basics in reading. Further, about 120 million of these had little or no experience of primary school, having not even reached grade 4 while the remaining 130 million were in primary school but had not achieved the minimum benchmarks for learning. In Kenya, the Uwezo Assessment report of 2010 and 2011 estimated that around 50 percent of children in grade 4 are not able to read grade 2 level work in Kenya. Often unable to understand a simple sentence, these learners were ill equipped to make the transition to secondary education owing to underperformance, a problem precipitated by reading difficulties 
and that has led to a learning crisis globally. Evidently, the performance standards among these groups of learners are challenged and require urgent redress. The Kenya government through the Ministry of Education has put in place primary school curriculum, structures and systems to enable learners acquire and develop ability to read and write which should eventually translate to good academic performance.

Notwithstanding the heavy investment in this endeavor, many public primary schools in Kenya have continued to perform poorly in the national examinations. This is partly due to learners' challenges in basic reading skills (Karanja, 2015). The consideration of the Uwezo Assessment report of 2010 and 2011, and the reoccurrence of the poor performance in national examinations in many public primary schools in Kenya, therefore, possess serious questions regarding the efficacy of the reading skills interventions among them comprehension monitoring (Onkoba, 2014; Karanja, 2015). Existing literature indicate dearth of studies in this area, which means little is known concerning the effects of reading skills interventions which would eventually affect the academic performance of public primary school pupils. Specifically, no study had been conducted in the low socio-economic urban centre of Western Zone in Nakuru Sub-County, Nakuru County, Kenya. In this sub-county, the public primary school pupils' average academic performance has been between 150 marks to 250 marks out of possible 500 marks (Nakuru County Education Office, 2017). The poor performance is largely attributed to the reading difficulties among many other factors. This presents a gap on the need to examine the reading difficulty interventions that are being used to mitigate this problem which is threatening the future level of education of pupils who undergo public primary schools. The present study, therefore, examined the effects of interventions of reading difficulties on academic performance of primary school pupils in Nakuru West Sub-County, Nakuru County, Kenya.

\section{Objective of the Study}

The objective of the study was to examine the effects of comprehension monitoring on academic performance of primary school pupils in Nakuru West Sub-County, Kenya.

Hypothesis

Consistent with the outlined objective, the study sought to test the following null hypothesis.

$\mathrm{HO}_{1}$ : Comprehension monitoring does not significantly influence academic performance of primary school pupils in Nakuru West Sub-County, Kenya.

\section{Literature Review}

\section{Theoretical Framework}

Since the study focused on the effect of comprehension monitoring as a intervention for reading difficulties, the Cognitive Model of Reading Comprehension by Walter Kintsch was used to underpin the research.

\section{Cognitive Model of Reading Comprehension}

The cognitive model of reading comprehension model was advanced by Kintsch (1998). The model incorporates the five different components involved in reading comprehension. There is 
an interrelationship among the comprehension components as represented in the construction - integration model (Kintsch, 1998).

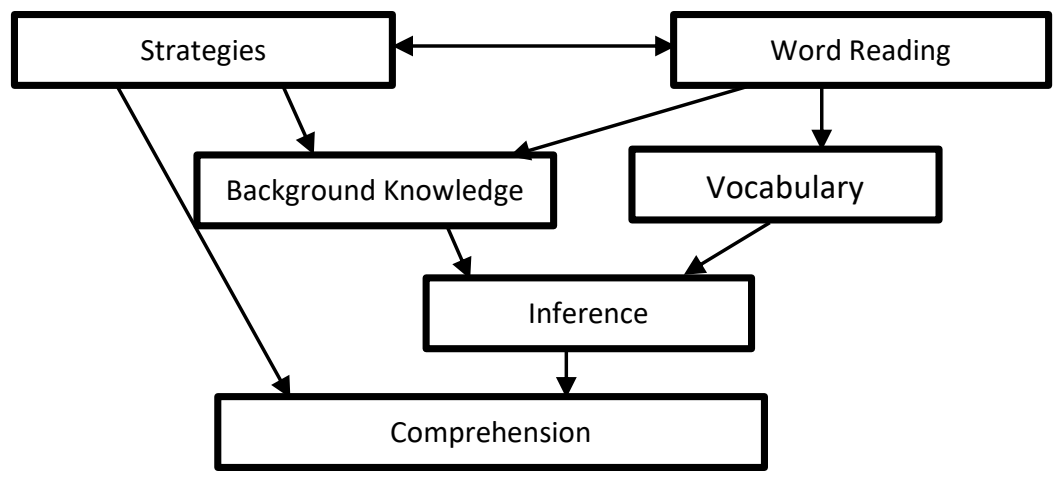

Figure 2.1. Construction- integration

Source: Kintsch (1998)

The Construction Integration (Cl) by Kintsch (1998) is a connectionist theory which proposes two phases in text comprehension which are construction phase and an integration phase. In the construction phase when a reader reads a word (decoding), it straight way activates that word plus all its meaning (vocabulary) in the long term memory (Graesser, Singer \& Tenebaum, 1994). The semantic associates of the word (from background knowledge) are activated, in the readers mind; a literal version of the text is constructed from the three components vocabulary, background knowledge and decoding. At the integration phase, there are two roles played by background knowledge. First, connections among nodes from long- term memory which depends on background knowledge (Whitney, Budd, Bramucci \& Crane, 1995). Second background knowledge is used to make inferences, elaborations and in text interpretation using domain- specific knowledge about texts (Kintsch \& Rowson, 2005).

Background knowledge has a strong impact on comprehension -All text structures require domain specific strategies and knowledge (Kintsch 1998). In familiar domains strategies are not necessary. Kintsch argues that no special strategies are required to make spatial inferences. From Figure 1, each arrow is a representation of a theoretical statement which states that there is a direct effect (path) from the variable at the tail of the arrow to the variable at the head of the tail. A curved double - headed arrow is a representation of a theoretical statement that the two statements are correlated. Absent arrows between a pair of variable is a representation of a theoretical statement that there is no direct effect between them. Strategies have a direct effect on reading comprehension and an indirect effect on reading comprehension via background knowledge and inference (Kintsch \& Rowson, 2005). Kitnsch argues that vocabulary has no direct effect on comprehension but an indirect one via inference. According to Kintsch in the construction integration model $(\mathrm{Cl})$ strongly emphasizes on the role of background knowledge in inference. 
Since the aim of reading is comprehension, this model provided a theoretical basis for tracing the comprehension path from word recognition to vocabulary mastery in comprehension monitoring. Thus, it will provide a sound basis for examining how teachers build on these to form reading strategies to help learners with reading disabilities improve their academic performance.

2.2 Comprehension monitoring intervention and academic performance of pupils The overall purpose of reading is comprehension. Comprehension is what reading is all about. It is the act or capability of understanding things especially what is written or spoken (Reader's Digest Oxford, 2014). Essentially, it's meaning derived from the act of reading. McEwan (2015) observes that each act of comprehension necessitates the reader's knowledge of the word as well. Comprehending a text is an interactive activity between the text and the reader's background knowledge. Efficient comprehension needs the power to relate textual material to one understands. Comprehending words, sentences and full text does not just depend on one's linguistic knowledge (Denton \& Al Otaiba, 2011). What we have a tendency to keep in mind of a text is not necessarily the wording of the text itself rather the meaning derived from it together with the inferences we've created during a single integrated whole (Mol \& Bus, 2011).

Reading comprehension as an activity involves three basic stages in succession; pre-reading, in reading and post reading stage (Ganimian \& Murnane, 2016). The pre-reading stage is meant for warm up activities that readies the readers for the reading task. An overview meant to increase reading efficiency is built at this stage. Several researchers concur that the pre-reading stage improves learner's comprehension of a text. The aim of the in-reading stage is to help the learner collate what he/she is reading, internalize the information, knowledge and opinions, follow the order of ideas within the text, to grasp and infer the knowledge contained the text and make confirmations of background knowledge (Kyle, Kujala, Richardson, Lyytinen \& Goswami, 2013). At this stage, it is imperative that learners observe and apply comprehension methods like stopping to summarize, asking queries, creating connections and watching comprehension (Hall, 2013). During the post reading stage, readers exercise their ability to summarize, clarify, connect and appraise as an indicator of understanding what they are reading (Richardson \& Lyytinen, 2014).

Mol and Bus (2011) explain that proficient text comprehension is influenced by: precise and fluent word reading skills oral language skills (vocabulary, linguistic comprehension); extent of factual and conceptual knowledge; knowledge and ability to use cognitive strategies to enhance comprehension or repair it once it breaks down; reasoning and inferential skills, and motivation to grasp and build interest within the task and materials (Mol \& Bus, 2011). In different words, a student's reading comprehension depends on: the level of knowledge he/she possesses, their thinking ability and their inspiration to carry out "the work" of comprehension (Richardson \& Lyytinen, 2014). A pupil should be able to read accurately, within the region of ninety-five percent of the words correctly in text to grasp what they are reading. Moreover, to grasp, a student should understand the meanings of ninety to ninety-five percent of the words being read (Ojanen, Rominus, Ahonen, Chansa-Kabali, February \& Jere-Folotiya, 2015).

The parts of reading comprehension play a significant role in comprehension activities. They embody vocabulary, information, strategies, reasoning and word reading (Wolf, Turner, Jukes \& 
Dubeck, 2018). Schema theorists postulate that information is crucial in comprehension activities; this is often recent data against that new data is mapped and eventually ends up in text comprehension (Kyle et al., 2013). Word reading includes the reader's word attack skills and sight words captured within the permanent memory. Word reading fluency plays a crucial role in comprehension for it attracts attention resources off from leaden process like the comprehension methods (Denton \& Al Otaiba, 2011). Vocabulary, that is, knowledge of the meaning of a word has emerged to among the strongest predictors of reading comprehension in both English as a primary language (EL1) and English as a second language (ESL) learners (Richardson \& Lyytinen, 2014). Inferring results in higher overall comprehension, additional engagement with the text, allows readers to see what lies further than the events of a story and also the text on the page and helps them to be Meta cognitive. These approaches essentially improve text comprehension. Studies have shown that increasing the reader's strategy skills cause substantial reading comprehension advantages (Kyle et al., 2013).

Over time, researchers have analyzed academic performance and reading comprehension across the globe and in Kenya seeking to establish the role of language in learners' academic achievement in numerous subjects. For instance, Cummins (1979) as cited in Onkoba (2014) studied language skills of bilinguals and found that that linguistic proficiency at a certain level appeared to be necessary for academic performance as a result of language competency permitting one to use it as for organization of knowledge and as a tool for reasoning. Other early research works also cited in Onkoba (2014) such as, Linvile (1970); Kopiyo (1982); Dawe (1983); and Muhandiki (1984) found out that reading comprehension significantly affected how pupils performed across several subjects.

Ming-San Chang (2013) examined academic language knowledge and comprehension science text for English language and fluent English speaking students in the US. The study investigated fifth-grade students' thoughts on text difficulty, their knowledge of the features of academic language, and the relationship between academic language and reading comprehension. Fortyfive fifth-grade students participated in the study; 18 students were classified as English language learners (ELLs) and 27 students were fluent-English speakers. The findings of the study revealed that vocabulary not grammar discourse features was significantly related to students' comprehension scores. Similarly, in the United Kingdom, MacGregor and Price (1999) cited in Chaseling, Boyd, Robson and Brown (2014) carried out a study on the relationship between reading comprehension and academic performance involving a sample of more than 1500 students, aged 11 to 15 , who were in their 1st to 4th years of algebra learning. The study observed that vocabulary, number and symbol sense, as well as the ability to read and comprehend, word problems were important factors affecting achievement in mathematics. Ombra (2010) findings were, however, contrary to previous studies as results on his study on deteriorating performance of Filipino in the national and international tests showed that the overall students 'reading skills were not significantly correlated to mathematics performance.

Onkoba (2014) investigated the relationship between reading comprehension practices and academic performance among class three pupils in Westland Sub-County, Kenya. The study findings confirmed that reading comprehension practices have an influence on academic 
performance and therefore there is a significant correlation between reading comprehension practices and academic performance. The findings also confirmed that there is a relationship between reading difficulties and academic performance. However, the study did not show how comprehension strategies were used to assist learners with reading difficulties. The present study, therefore, seeks to investigate how comprehension strategies are used as interventions focusing on learners with reading difficulties and how this eventually reflects in their academic performance.

Reading challenge can be overcome through; development of sensitive and valid screening measures; professional development and use of a professional common language; implementation of three-tier models; continuous assessment of progress, and; appreciation of school leadership and capacity factors (Giess et al., 2012). Early intervention is, however, possible. This involves assessing all children and intervene- first in the classroom and then through supplemental instruction (Scanlon, Anderson \& Sweeney, 2016). Also monitoring their understanding of the text, making adjustments in their reading as necessary. Good readers try to determine the meaning of unfamiliar words and concepts in the text, and deal with inconsistencies or gaps as needed (Piper, Zuilkowski \& Mugenda, 2014).

Early intervention is effective. Studies in overcoming reading difficulties in Organization for Economic Cooperation and Development (OECD) countries like the US and Western Europe (Kenya not included) ordinarily show that between $70 \%$ - $90 \%$ of pupils at risk will learn to read on an average scale (Denton, 2012; Scanlon et al., 2016). This necessitates the instructors to give ample opportunities for guided exercising of newly acquired skills; give a major increase in intensity of instruction, and; give systematic and express instruction on part skills that show deficiency (Giess et al., 2012). Interventions are instrumental once they give acceptable levels of support as learners learn to use new skills (Piper et al., 2014). However, even the perfect intervention programs leave behind $2-6 \%$ of learners. Therefore, it is important to scale back the numbers so as to effectively implement remedial programs (McEwan, 2015).

If pupils do not have the specific background knowledge, the teacher should help them to build their knowledge by teaching reading strategies and skills, and knowledge about the text. Reading widely broadens the background information, thus providing the pupils with better knowledge base with which to relate to their subject textbooks and lessons (Piper et al., 2014). Chou and Cheng (2015) indicated that, reading volume is a predictor of comprehension and cognitive ability (building their vocabulary and general knowledge). Rahim (2018) recommends that, students need a lot of academic texts which require them to use higher levels of reading skills and comprehension. Unfortunately, many students avoid this and go for light reading like newspaper and entertaining magazines (Denton \& Al Otaiba, 2011). This leads to poor academic achievement as they move to higher levels of learning.

Athiemoolam and Kibui (2012) did an analysis of Kenyan learners' proficiency in English based on reading comprehension and vocabulary. It was evident from the study that Kenyan learners were experiencing challenges with the interpretation and application of reading comprehension and vocabulary skills that are essential to the promotion of effective reading with the focus on making meaning. Some reading difficulties experienced by the learners within the context of their study 
could be attributed to problems external to the reader which could include a lack of background knowledge, the way texts are written and organized, the style and complexity of the language, an impoverished reading culture and environment, and inadequate experience and exposure to the manifold contexts in which reading occurs (Athiemoolam \& Kibui, 2012). Moreover, poor teaching can both initiate and perpetuate reading difficulties for learners. The study proposed that teachers should use teaching methods that would improve their learners' predictive and interpretive skills relating to reading comprehension (Hall, 2013). Finally, learners should be aware that becoming a good reader takes time and involves sustained reading effort. With guidance and support from their teachers and a great deal of exposure to different genres, learners will, over time, have the opportunity to become proficient readers with enhanced interpretive, critical and analytical skills (Ganimian \& Murnane, 2016).

Omwega, Amimo and Role (2014) examined how reading skill deficiency could be the main barrier in the participation of Kenyan pupils in the global space. The findings revealed that students lacked proficiency in reading - only attaining the level described as fair; suggesting that the pupils lagged behind in global information. Girls had better reading skills than boys. The study recommends that there should be a constant supply of a variety of reading materials at home and school; more emphasis on the aesthetic value of reading and establishment of school libraries. Piper and Zuilkowski (2015) assessed reading fluency in Kenya using oral or silent assessment interventions. The study compared standard two pupils' scores on oral and silent reading tasks of the lower primary school pupils in Kiswahili and English, and found no statistically significant differences in either language. The study did, however, found oral reading rates to be more strongly related to reading comprehension scores. Oral assessment was reported to having another benefit for program evaluators - it allows for the collection of data on student errors, and therefore the calculation of words read correctly per minute, as opposed to simply words read per minute. The authors, therefore, recommended that, in Kenya and in similar contexts, student reading fluency be assessed via oral rather than silent assessment.

The findings of the studies reviewed in this subsection provide evidence on the importance of reading comprehension interventions in addressing reading difficulties among learners of different age groups. However, the studies did not link reading comprehension with learners' academic performance.

\section{Research Methodology Location of the Study}

The study was carried out in Nakuru West Sub-County, Nakuru County - Kenya. Nakuru County is one of the Counties in Rift Valley region, Kenya. Nakuru is an agriculturally-rich county and is blessed with various tourist attractions such as craters and lakes such as Lake Nakuru. It's made up of 11 constituencies which also double up administratively as sub counties. Nakuru Town West is one of the sub counties of Nakuru County (Nakuru County Government, 2017). The area is highly cosmopolitan and has 12 public primary schools with a teacher population of 812 teachers of which 342 are language teachers. The area is also densely populated and classified as a low income area. The area has several private and public secondary schools and also public and 
private primary schools and ECD centre's, however, higher learning institutions are scarce in this area. The socio-demographic patterns in the area are unique compared to other sub-counties in Nakuru County, hence, making it an information rich study area.

\section{Research Design}

This study used both descriptive survey design and experimental design. The descriptive survey e design is useful in obtaining both qualitative and quantitative data. The design enabled the study to collect the respondent's attitudes and opinions concerning the research problem over a wide area are a descriptive format. These descriptions can then be subjected to various forms of statistical analysis for inference and generalizations. The study also used the experimental design to test the learners reading difficulties after interventions. Kothari (2004) explains that an experimental design is one in which the independent variable is manipulated. The two research designs complemented each other as to provide insight into the problem being investigated in the study.

\section{Target Population}

The study targeted 12 primary schools in the area as its unit of analysis. From these 342 language teachers, that is, English and Swahili teachers were targeted. The study only involved language teachers in the upper primary levels due to the fact that the study also involved reading comprehension test which was not applicable to the lower primary learners. Since this study was about reading difficulties interventions, the study also targeted pupils with reading difficulties. These were drawn from the upper primary classes that are from class four to class eight in various schools in the study area. The area has 14,158 classes one to class eight pupils enrolled in the public primary schools in the area. According to a national survey on children with learning disabilities of which reading difficulties form part at $8 \%$ of the total population of children in primary schools (KISE, 2018). Therefore, $8 \%$ of the 14,158 pupils gives 1133 pupils who have reading difficulties. The inclusion criteria for learners with reading difficulties required that only those learners who their teachers identified as having consistent reading difficulties were included in the study. The learners were identified by their language teachers from their regular class exercises and were drawn from class four up to class eight. As the study was also experimental in nature, the learners identified with reading difficulties were categorized into two groups of equal proportion. Group A was the control group and this group was not subjected to reading difficulties interventions while Group B was the experimental group and were subjected to the reading difficulties interventions.

\section{Sample Size and Sampling Techniques}

Singh and Masuku (2012) define sampling as a procedure of selecting members of a research sample from the accessible population which ensures that conclusions from the study can be generalized to the study population. Since the number of schools in the area is 12 , a census approach was appropriate. From these 1,475 subjects were of interest to the study, that is, 342 teachers and 1133 pupils. Therefore, in order to obtain a representative sample size for the pupils 
which are a bigger population, while keeping the size manageable, the study used the formula proposed by Nassiuma (2000). This formula enabled the researchers to minimize the error and enhance stability of the estimates. Thus;

$$
n=\frac{N c^{2}}{c^{2}+(N-1) e^{2}}
$$

Where $\mathrm{n}=$ sample size, $\mathrm{N}=$ population size, $\mathrm{c}=$ coefficient of variation $(\leq 50 \%)$, and $\mathrm{e}=$ error margin ( $\leq 5 \%)$. Substituting into the formula:

$$
n=\frac{1133 *(0.3)^{2}}{(0.3)^{2}+(1133-1) *(0.03)^{2}}=91.9643 \approx 92
$$

Therefore, a sample size of 92 of pupil respondents was obtained from the above formula. To obtain the sample size for the teachers, the study used $20 \%$ of the population as recommended by Mugenda and Mugenda (2003) who says a sample size of between $10 \%$ and $30 \%$ can be representative of the entire population when the population is small. Therefore, the sample size of teachers was 68. Hence, the resultant proportionate subjects are shown in Table 1.

\section{Table 1}

Sample Size Distribution

\begin{tabular}{lcc}
\hline Teacher category & Population & Sample size \\
\hline Language teachers & 342 & 68 \\
Control Group A & 566 & 46 \\
Experiment Group B & 567 & 46 \\
Total population & $\mathbf{1 4 7 5}$ & $\mathbf{1 6 0}$ \\
\hline
\end{tabular}

The present study used purposive sampling to select teachers and stratified random sampling to select the pupils according to their categories as shown in Table 3.2. The teachers who regularly teach languages in upper classes were purposively identified by their head teachers on the basis of availability, that is, those who could avail themselves individually for filling the questionnaires and also those who were willing to allow the comprehension and observation exercises to be carried out during their lessons.

Since the study also targeted pupils with reading difficulties, the language teachers who volunteered to participate in the study selected the learners with reading disabilities first based on their experience with them. They purposefully selected 10 pupils who had moderate to severe reading difficulty problems in each class and these were split into two groups-Group A and Group B. One group -Group B was subjected to reading difficulties interventions while the other being the control group did not receive any interventions. Their performance was then assessed and compared using the reading comprehension test. 


\section{Instruments of Collecting Data}

Research instruments are tools used to collect the necessary information for a study. In this study, the researcher made use of the questionnaires, reading test adapted from Karanja (2015) and observation schedule to collect data. The questionnaires had closed (structured) items scored on a five point Likert scale and were divided into sections describing the variables of the study. The questionnaires were administered to the teachers and collected on the material day of administration. The questionnaire items were derived from the literature review done in this study

The observation schedule was also used in the study to capture the actual interplay of the variables of interest during class sessions between teachers and pupils in upper primary school. The researcher was non-participant in the class sessions and only observed the way the lessons are conducted so as to establish how the variables manifest during the sessions

The study also used a reading test adapted from Karanja (2015) (see Appendix IV) to test the reading difficulties of the pupils in the schools. This instrument was administered to two groups of learners where learners identified as having demonstrable reading difficulties by their teachers in upper primary school and were not given interventions during the study were labelled as the Control Group A while learners who had reading difficulties but were given reading difficulties interventions were labelled as Experimental Group B.For the purposes of control and comparison, the instrument was administered from an equal number of pupils who have not manifested any reading difficulties from the respective schools. Once identified, the pupils were required to take the test in seclusion with only the researcher or her assistants and the teacher as the audience at a convenient location and time within the school and their privacy during the process was upheld.

Piloting was done with a pilot group of 15 respondents; five teachers and ten pupils drawn from two primary schools in the neighboring Nakuru East Sub-County - which had comparable characteristics - before the actual collection of data. The pilot group was purposively chosen with the assistance of head teachers of the two schools. The pre-testing was meant to enable the researcher discover the weakness of the research instruments which may arise during the actual study and affect the findings. This included, checking the clarity of the questionnaire items and also comments elicited from the pilot group that could assist the researcher reconstruct the questionnaires for the purposes of improvement. The internal consistency approach was used to determine the reliability of the instruments. The Cronbach's coefficient alpha was applied on the results obtained from the pilot test to determine how items correlate among them in the same instrument. Cronbach's coefficient Alpha of more than 0.7 was considered acceptable for the purposes of the study. A reliability coefficient $\dot{\alpha} \geq 0.70$ was, therefore, adopted for this measure.

\section{Data Presentation and Analysis}

The researcher used the computer software Statistical Package for Social Scientists (SPSS) version 21.0 to conduct initial data analysis using simple descriptive statistical measures such as, mean, 
standard deviation and variance to give glimpse of the general trend. In addition, correlation analysis was used to determine the nature of the relationship between variables at a generally accepted conventional significant level of $P \leq 0.05$ (Sekaran, 2012). Data from the reading tests were marked by the researcher and then compared between the two experiemental groups using the One-Way ANOVA. The results from the observation schedules were also analyzed descriptively and used to provide supporting narratives to the study.

\section{Results and Discussions Introduction}

This chapter presents results arising from the analysis of data collected using questionnaires. The data collected was analyzed using descriptive and inferential statistical methods where the findings are presented in tables and figures, and their implications discussed.

4.2 Reliability Statistics

Before administering the questionnaire to the teachers for data collection, the reliability analysis of the instrument was carried out to determine whether data was indeed reliable for its intended purposes. The Cronbach Alpha value was computed and the results are as presented in Table 1.

Table 1

Reliability Statistics

\begin{tabular}{cc}
\hline Cronbach's Alpha & N of Items \\
\hline 0.974 & 11 \\
\hline
\end{tabular}

The results in Table 1 shows that the questionnaire was highly reliable for the study as indicated by the alpha value that is way above the recommended value of 0.7 (Marshall \& Rossman, 2014). As the Cronbach Alpha coefficient was very high, there was no need to substantially revise the instrument; hence, it was administered after being scrutinized for any omission or punctuation errors.

\section{Response Rate}

The study administred 68 questionnaires to the teachers sampled in the study and obtained the response rate of completed questionnaires shown in Table 2.

\section{Table 2}

\section{Questionnaire Response Rate for Teachers}

\begin{tabular}{ccc}
\hline $\begin{array}{l}\text { No. of questionnaires } \\
\text { Issued to teachers }\end{array}$ & No. of questionnaires Returned & Response Rate (\%) \\
\hline 68 & 57 & 86 \\
\hline
\end{tabular}

The high questionnaire response rate (86\%) shown in Table 2 was acceptable according to Babbie (2015). The other questionnaires were not returned by the respondents, hence, they were not 
INTERNATIONAL JOURNAL OF ACADEMIC RESEARCH IN BUSINESS AND SOCIAL SCIENCES

Vol. 9, No. 11, November, 2019, E-ISSN: 2222-6990 ㄷ 2019 HRMARS

included in the study. The study also administered a reading comprehension test to 59 out of the 96 pupils sampled as shown in Table 3.

\section{Table 3}

Response Rate for pupils who participated in comprehension tests

\begin{tabular}{ccc}
\hline $\begin{array}{l}\text { No. of pupils targeted for } \\
\text { comprehension tests }\end{array}$ & $\begin{array}{l}\text { No. of pupils who participated } \\
\text { in comprehension tests }\end{array}$ & Response Rate (\%) \\
\hline 92 & 59 & 64 \\
\hline
\end{tabular}

Response rate for pupils who participated in comprehension tests was $64 \%$ as shown in Table 3 . The response was high and acceptable for the study purposes. According to Maxfield and Babbie (2014), a response rate of $50 \%$ is acceptable for studies of this kind while Onen and Oso (2009) rates instrument response rates above $70 \%$ as very good. $41 \%$ of the targeted pupils were not able to participate in the study due to the fact that their schools were having examinations at the time of conducting the study and as such they could not avail the pupils for the tests.

4.4 Comprehension monitoring intervention and academic performance of pupils The results of the effects of comprehension monitoring, described in terms of pre-reading, reading and post-reading after an intervention initiative, on academic performance of primary school pupils in Nakuru West Sub-County are presented in Table 4. 
INTERNATIONAL JOURNAL OF ACADEMIC RESEARCH IN BUSINESS AND SOCIAL SCIENCES

Vol. 9, No. 11, November, 2019, E-ISSN: 2222-6990 @ 2019 HRMARS

Table 4

Comprehension Monitoring Intervention and Academic Performance of Pupils

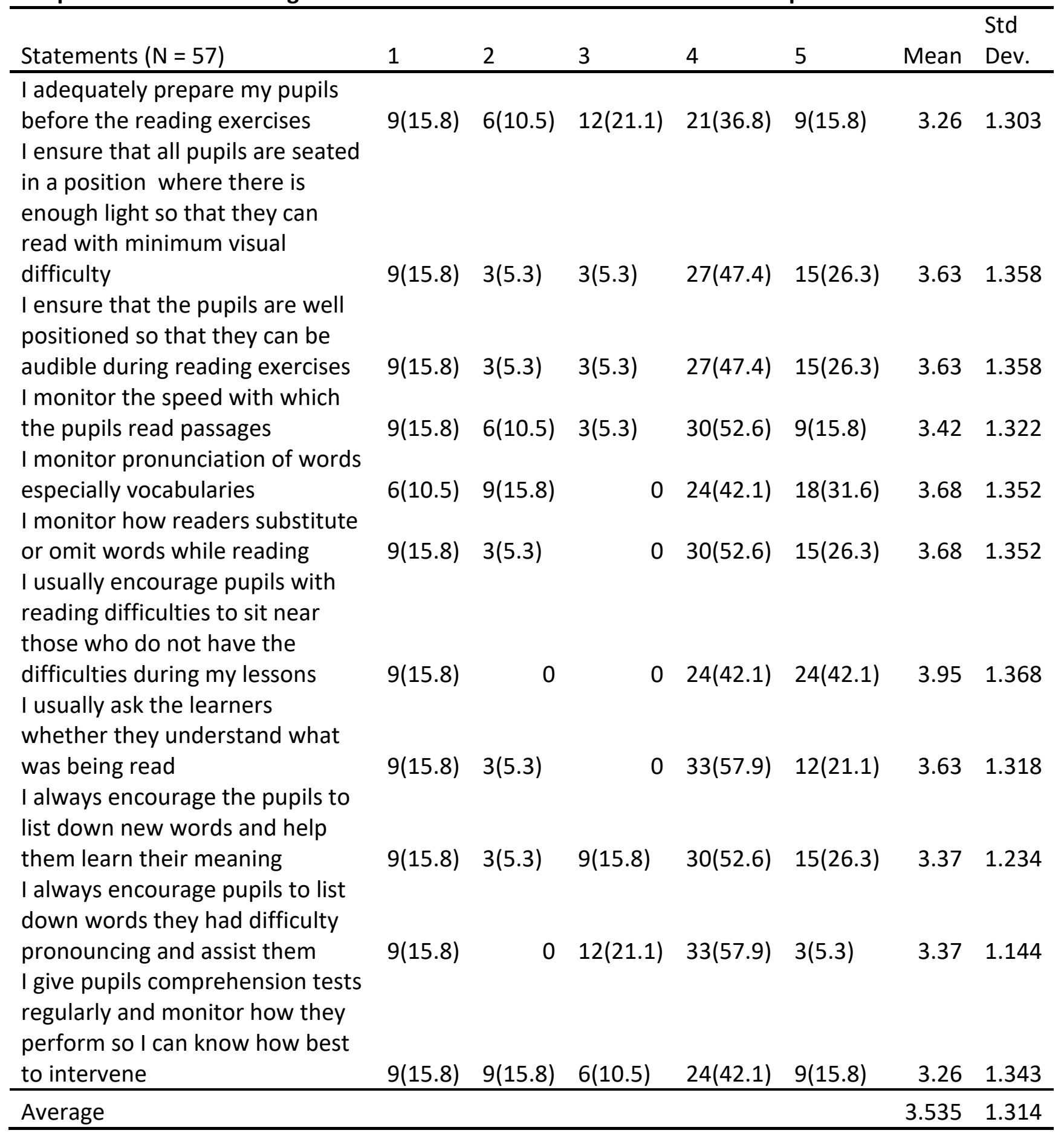


The overall mean of the responses (mean $=3.535$ ) in Table 4 is above 3.5 indicating that most of the teacher respondents were in agreement with assertions made regarding their application of comprehension monitoring to remedy reading difficulties and their effects on academic performance of pupils in their schools. The top three comments, for instance, suggest that majority of the teachers usually encourage pupils with reading difficulties to sit near those who do not have the difficulties during their lessons (mean = 3.95). Most teachers monitor pronunciation of words especially vocabularies (mean $=3.68$ ) and also monitor how readers substitute or omit words while reading (mean $=3.68$ ). This shows that the teachers were more concerned about the reading phase of comprehension than the other two phases of pre-reading and post reading. According to Kyle et al., (2013), Hall (2013) and Richardson and Lyytinen (2014), while the in-reading stage was important, it was important that the other stages too be given sufficient attention so as to improve the comprehension cycle.

The findings further suggest that most teachers prepared their pupils at the pre-reading phase as suggested by their agreements with the two statements; I ensure that all pupils are seated in a position where there is enough light so that they can read with minimum visual difficulty (mean $=3.63$ ) and $I$ ensure that the pupils are well positioned so that they can be audible during reading exercises (mean $=3.63$ ). Further, comparably fewer teachers agreed that adequately prepare their pupils before the reading exercises (mean $=3.26$ ). However, in the researcher's observations, in most schools, majority of the classrooms were not well lit and were congested, making it difficult for the learners to move to areas where there was enough light. These findings imply that the teachers did not adequately prepare their learners well during the pre-reading stage especially with regard to the subject matter. As such the pupils were seldom ready for the in-reading exercise. Ganimian and Murnane (2016) had explained that the pre-reading stage is a very important stage that gives the learner an overview that increases reading efficiency and improves the learner's comprehension of a text.

However, the teachers put less emphasis on the post reading stage as suggested by their low rating of the statements regarding this phase of reading; I always encourage the pupils to list down new words and help them learn their meaning (mean $=3.37$ ) and I always encourage pupils to list down words they had difficulty pronouncing and I assist them (mean = 3.37). It was also evident that fewer teachers gave their pupils comprehension tests regularly and monitored how they perform so that they could know how best to intervene (mean = 3.26). The comparably low means on the post reading constructs suggests that it was not given much emphasis, although, this was an important stage of reading. The finding that fewer teachers gave their pupils comprehension tests regularly goes against the Giess et al., (2012) who recommended continuous assessment of progress among other interventions for remedying reading challenge. Also according to Scanlon et al., (2016), monitoring their [pupils] understanding of the text, making adjustments in their reading as necessary was important. 
These findings imply that the pupils were not adequately prepared by their teachers during comprehension with the focus of teachers being concentrated on the reading phase. Also the post reading phase was less emphasized than the other two phases of reading. Observations made during the lessons confirmed that teachers did not adequately prepare the learners for the reading assignment at the pre reading stage. However, during the in-reading stage, they tended to put much emphasis on how the pupils read. In the post reading stage, the teachers were only particular in finding out what the learners could summarize from the text as opposed to, say, recalling new words and their meanings. This was indicative of inadequate comprehension monitoring practices by teachers in the schools. Indeed, Hall (2013) observed that poor teaching can both initiate and perpetuate reading difficulties for learners. Hall's study proposed that teachers should use teaching methods that would improve their learners' predictive and interpretive skills relating to reading comprehension. Giess et al., (2012) had also recommended that instructors give ample opportunities for guided exercising of newly acquired skills; give a major increase in intensity of instruction, and; give systematic and express instruction on part skills that show deficiency.

4.5 Academic performance of primary school pupils in Nakuru West Sub-County The study sought to determine the status of academic performance of primary school pupils in Nakuru West Sub-County described in terms of mastery of subject skills, test scores and assignments are presented in Table 5 
INTERNATIONAL JOURNAL OF ACADEMIC RESEARCH IN BUSINESS AND SOCIAL SCIENCES

Vol. 9, No. 11, November, 2019, E-ISSN: 2222-6990 @ 2019 HRMARS

Table 5

Academic performance of primary school pupils in Nakuru West Sub-County

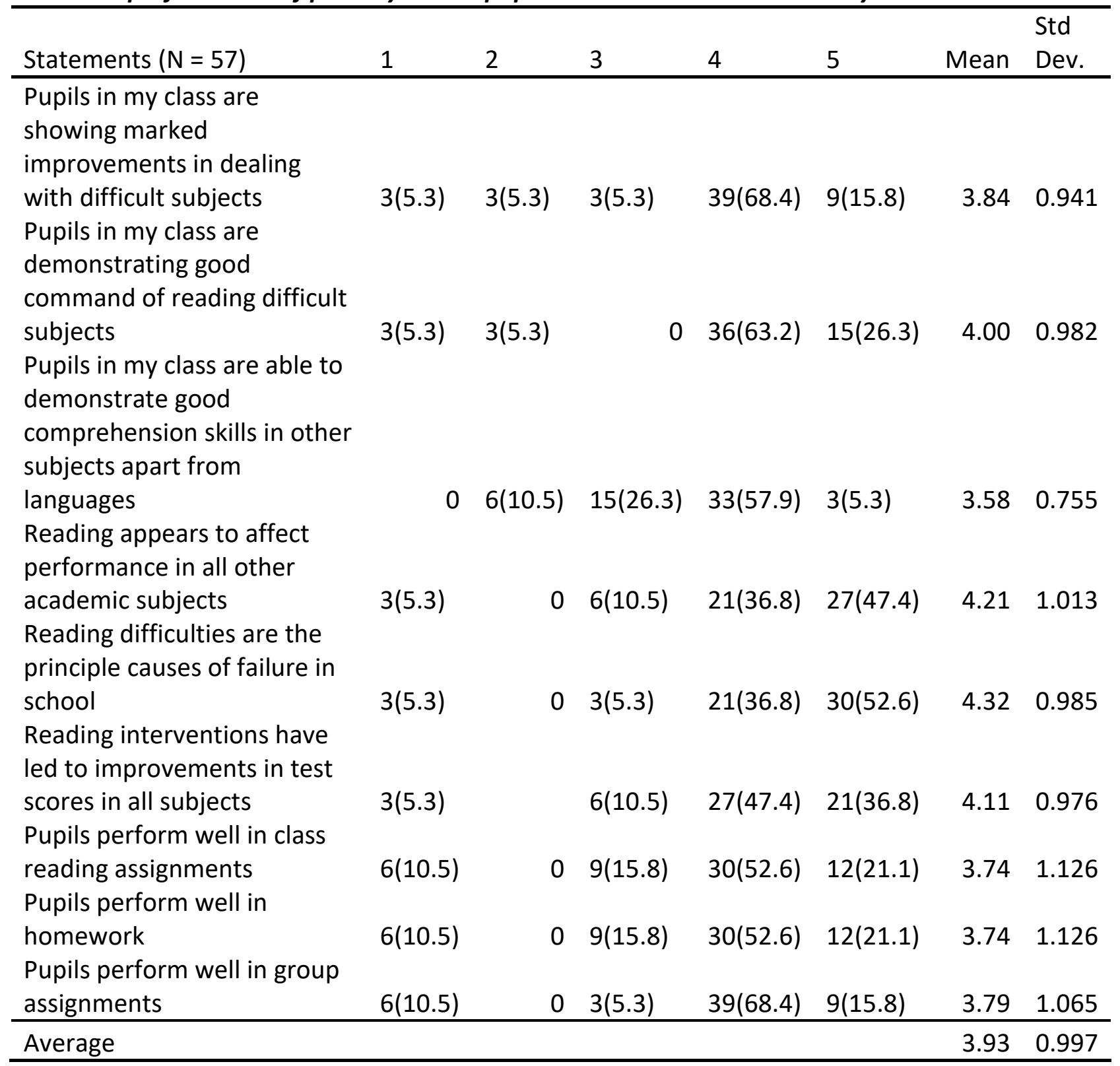

It is evident from the responses in Table 5 that majority of the teachers strongly agreed with all the statements describing academic performance of the pupils in their schools as indicated by the high overall mean for the responses (mean $=3.93$ ). However, it was evident that most teachers were concerned with the reading difficulties their pupils were experiencing, and linking to academic performance as suggested by the top two statements; reading difficulties are the principle causes of failure in school (mean $=4.32$ ) and reading appears to affect performance in 
all other academic subjects (mean = 4.21). Nevertheless, most of them felt that their interventions were having a substantial effect on academic performance as indicated by their rating of the statement; reading interventions have led to improvements in test scores in all subjects (mean $=4.11$ ). The least rated statement (mean $=3.58$ ) showed that most teachers were of the view that pupils in their class were able to demonstrate good comprehension skills in other subjects apart from languages.

These findings imply that the academic performance of the learners was to a considerable extent affected by the reading difficulties. The findings agree with Cimmiyotti (2013) in the US, Yamashita and Hayashi (2014) in Japan, and Onkoba (2014) and Karanja (2015) in Kenya whose studies found that reading difficulties affected the academic performance of pupils. Specifically, students who had fewer problems with word substitution, omission, mispronunciation and addition scored highly in the end of the term exams. However, they disagree with Oberholzer (2015) in South Africa who failed to find any significant correlation between reading difficulties and academic performance.

\section{Inferential Statistics}

To evaluate the relationships between the dependent and independent variables and subequently test the hypothesis, a bivariate regression analysis was done and the findings discussed as follows.

Table 6

Linear Regression Analysis Model Summary

\begin{tabular}{|c|c|c|c|c|c|}
\hline & \multicolumn{2}{|c|}{$\begin{array}{l}\text { Unstandardized } \\
\text { Coefficients }\end{array}$} & $\begin{array}{l}\text { Standardized } \\
\text { Coefficients }\end{array}$ & \multirow[t]{2}{*}{$\mathrm{t}$} & \multirow[t]{2}{*}{ Sig. } \\
\hline & $\mathrm{B}$ & Std. Error & Beta & & \\
\hline (Constant) & 26.294 & 2.872 & & 9.155 & 0.000 \\
\hline Comprehension Monitoring & 0.232 & 0.07 & 0.407 & 3.306 & 0.002 \\
\hline R Square & 0.166 & & $\mathrm{~F}$ & 10.93 & $(1,55)$ \\
\hline Adjusted R-Square & 0.151 & & Sig. & $.002 b$ & \\
\hline
\end{tabular}

a Predictors: (Constant), Comprehension Monitoring

Dependent Variable: Academic Performance

The study sought to determine whether comprehension monitoring had a significant relationship with academic performance of primary school pupils in Nakuru West Sub-County. The regression analysis in Table 6 indicates that there was indeed a significant relationship $(\beta=0.407, p=0.002$ $<p=0.05$ ) between the variables. The result suggests that there was a moderate but positive relationship between the variables indicating that comprehension monitoring as was currently being done by the teachers in the schools surveyed was significantly influencing academic 
performance of primary school pupils in the area. The r-square $\left(R^{2}=0.166\right)$, further, indicates that the model could explain upto $16.6 \%$ of the variations in the academic performance of primary school pupils in Nakuru West Sub-County. It also suggests that the model could improve when more predictive variables were incoporated into the model. Further, from the ANOVA results, it is evident that there is a significant difference between means of variables predicting reading difficulties interventions and the mean of variable predicting academic performance of primary school pupils in Nakuru West Sub-County $\left(F_{o^{\prime}}=10.93>F_{c}=4.00 ; \alpha<0.05 ; d f=1,55 ; p=\right.$ $0.000<p=0.02$ ). This finding also indicates that the dependent variable, that is, the academic performance of the pupils, would change by a corresponding number of standard deviations when the comprehension monitoring as an intervention changed by one standard deviation. Further, the model constant is significant $(p<0.05)$ which suggests that there were other factors not included in the model which affected the pupils academic performance in the schools. The study therefore establishes that comprrhension monitoring had visible effects on academic performance of the pupils with reading difficulties in the schools and, therefore, should not be overlooked when carrying out interventions for academic performance in the schools. The resulting regression model, therefore, holds under;

$$
y=26.294+0.232 \times \text { or, }
$$

Academic Performance of Pupils $=26.294+0.232$ Comprehension Monitoring

The following null hypothesis was subsequently tested.

\section{$\mathrm{HO}_{1}$ : Comprehension monitoring does not significantly influence academic performance of primary school pupils in Nakuru West Sub-County}

It is evident from the results in Table 6 , it is evident that there was indeed a significant relationship between the variables $(r=0.407, p=0.002<p=0.05)$. This meant that the null hypothesis was rejected. Therefore, it can be inferred that comprehension monitoring as currently practiced in the schools did translate to academic performance of primary school pupils in Nakuru West Sub-County.

These findings agree with those of Piper and Zuilkowski (2015) whose study on reading assessment interventions revealed that reading rates were more strongly related to reading comprehension scores. These results also agree with those of previous studies, for example, Cummins (1979) cited in Onkoba (2014) who found that linguistic proficiency at a certain level appeared to be necessary for academic performance. Linvile (1970), Kopiyo (1982), Dawe (1983) and Muhandiki (1984) also cited in Onkoba (2014) similarly found out that reading comprehension significantly affected pupils' performance across several subjects. The results, however, disagree with In South Africa, Oberholzer (2015) whose study failed to find any significant correlation between reading difficulties and academic performance.

\section{Results from the Reading Test Experiment}

The study also sought to establish whether there was a significant difference in reading improvement among leaners with reading difficulty in two groups after subjecting them to 
interventions. Two groups were used, the first being the Control (Group A) that did not receive interventions and the other Experiment (Group B) that was subjected to the interventions. A comprehension experiement requiring the learners to read a 187 words passage was given to the learners selected from each group after the interventions and each learner allocated two minutes to read the script. After reading they were given time to answer the comprehension questions over the lesson. The comprehension test was assessed on the basis of the speed of completing reading the passage, number of mispronouced words, omitted words, substituted words, merged words and how well the pupils answered the comprehension test scores. The results are presented in Table 7.

\section{Table 7}

\section{Reading Test Results}

\begin{tabular}{|c|c|c|c|c|c|c|c|}
\hline$N=59$ & Variable & Class 4 & Class 5 & Class 6 & Class 7 & Class 8 & Average \\
\hline \multirow{8}{*}{$\begin{array}{l}\text { Control } \\
\text { (Group A) }\end{array}$} & Speed* & $28 \%$ & $33 \%$ & $33 \%$ & $38 \%$ & $40 \%$ & $35 \%$ \\
\hline & Mispronounced words & $49 \%$ & $52 \%$ & $46 \%$ & $41 \%$ & $40 \%$ & $45 \%$ \\
\hline & Omitted words & $55 \%$ & $51 \%$ & $44 \%$ & $35 \%$ & $35 \%$ & $45 \%$ \\
\hline & Substituted words & $31 \%$ & $22 \%$ & $25 \%$ & $20 \%$ & $19 \%$ & $22 \%$ \\
\hline & Merged words & $11 \%$ & $9 \%$ & $11 \%$ & $15 \%$ & $8 \%$ & $11 \%$ \\
\hline & Average reading test & & & & & & \\
\hline & scores & $35 \%$ & $33 \%$ & $32 \%$ & $30 \%$ & $28 \%$ & $32 \%$ \\
\hline & Post reading Test scores & $35 \%$ & $33 \%$ & $36 \%$ & $36 \%$ & $41 \%$ & $47 \%$ \\
\hline \multirow{8}{*}{$\begin{array}{l}\text { Experiment } \\
\text { (Group B) }\end{array}$} & Speed* & $47 \%$ & $50 \%$ & $53 \%$ & $59 \%$ & $66 \%$ & $55 \%$ \\
\hline & Mispronounced words & $33 \%$ & $29 \%$ & $30 \%$ & $25 \%$ & $20 \%$ & $27 \%$ \\
\hline & Omitted words & $17 \%$ & $17 \%$ & $13 \%$ & $11 \%$ & $8 \%$ & $13 \%$ \\
\hline & Substituted words & $12 \%$ & $10 \%$ & $11 \%$ & $7 \%$ & $7 \%$ & $9 \%$ \\
\hline & Merged words & $10 \%$ & $10 \%$ & $4 \%$ & $5 \%$ & $1 \%$ & $6 \%$ \\
\hline & Average reading test & & & & & & \\
\hline & scores & $24 \%$ & $23 \%$ & $22 \%$ & $21 \%$ & $20 \%$ & $22 \%$ \\
\hline & Post reading Test scores & $55 \%$ & $60 \%$ & $60 \%$ & $65 \%$ & $70 \%$ & $62 \%$ \\
\hline
\end{tabular}

*Based on words completed in the entire passage in the allocated two minutes

The results of the reading test in Table 7 reveal that there were notable discrepancies in the reading performance of the pupils from both categories. The average reading test scores shows that more pupils who had not received interventions (35\%) than those who had not received the interventions (22\%) manifested reading difficulties. Notably, the learners in the control group $A$ 
were on average, able to read up to $35 \%$ of the 187 -word passage in the allotted two minutes while their counterparts who had received the interventions were able to read up to $47 \%$ of the passage on average within the allotted two minutes. Majority of the learners in Control Group A who had not received interventions also manifested problems with other aspects of reading such as mispronoucation of words, omission of words, substitution of words and merging of words compared to their colleagues without the reading difficulty problem.

Further, when it came to the post reading comprehension tests, it was evident that there was still a problem with comprehension among both groups with pupils in the experiment scoring $62 \%$ on average while their counterparts with reading difficulties who scored $47 \%$ on average. It is also evident from the finding that the reading performance of the learners increased as they progressed through class levels. For example, 55\% of learners in the Control Group A in class four omitted words during the tests while only $35 \%$ of learners in class 8 omitted words. The same trend was aobserved among pupils in the Experiment Group B where $17 \%$ of the class four learners omitted words while $8 \%$ of the class 8 learners ommitted words in the reading comprehension tests.

The results suggest that there was a serious problem with reading which was attributable to among other things poor phonological awareness. According to Jukes et al., (2017) indicates that reading failure is principally caused by failure to obtain phonological awareness and skills in alphabetical coding. Further, as evidenced by the both the reading and post reading test scores, it was evident that majority of the learners fell below the threshold prescribed by Ojanen et al., (2015) who recommended that a pupil should be able to read accurately, within the region of ninety-five percent of the words correctly in text to grasp what they are reading. Omwega et al., (2014) also found that students lacked proficiency in reading - only attaining the level described as fair; suggesting that the pupils lagged behind in global information. The findings also support those of

Mwanamukumbi (2013) who found that grade levels affected the pupils' fluency of reading and also further noted that as pupils continued reading, they committed errors like substituting, mispronouncing, adding and omitting some words.

The results of the comprehension tests between the two groups were subjectd to a One-Way ANOVA test to establish whether there was indeed a significant difference between the reading difficulties between both groups of learners. The results are presented in Table 8. 
Table 8

ONE-WAY ANOVA Results for the Reading Tests

\begin{tabular}{lrr}
\hline Test Variable & F & Sig. (2-tailed) \\
\hline Speed* & 6.19 & 0.001 \\
Mispronounced words & 8.22 & 0.001 \\
Omitted words & 4.44 & 0.005 \\
Substituted words & 3.35 & 0.033 \\
Merged words & 2.76 & 0.110 \\
Post reading Test scores & 3.99 & 0.005 \\
\hline
\end{tabular}

It is evident from the results in Table 8 that the means of performance on the reading test was significantly different between both groups of pupils except for the merging of words $(F=2.76$; $p=0.110>p=0.05)$. This implies that despite the interventions being carried out made a difference in reading performance of the learners. These results concur with those of Oyetunde et al., (2016) whose study on strategies that work on improving literacy instructional practices in primary schools in Nigeria revealed that the treatment group significantly outperformed the control group on all nine reading skills sub-tests.

\section{Summary, Conclusions and Recommendations Summary}

The present study sought to examine the effects of comprehension monitoring as an intervention on academic performance of primary school pupils in Nakuru West Sub-County, Kenya. The results from the overall mean of the responses (mean $=3.535$ ) in Table 4 indicated that most of the teacher respondents were in agreement with assertions made regarding their application of comprehension monitoring to remedy reading difficulties and their effects on academic performance of pupils in their schools. The findings specifically revealed that the teachers were mostly concerned about the reading phase of comprehension than the other two phases of prereading and post reading. Further, the findings revealed that the teachers did not adequately prepare their learners well during the pre-reading stage especially with regard to the subject matter and put less emphasis on the post reading stage as suggested by their low rating of the statements regarding this phase of reading. Hence, it was evident that the pupils were not adequately prepared by their teachers during comprehension with the focus of teachers being concentrated on the reading phase. Also the post reading phase was less emphasized than the other two phases of reading. Observations made during the lessons confirmed this to be so. In 
addition, from the researcher's observations, in most schools, majority of the classrooms were not well lit and congested making it difficult for the learners to move to areas where there was enough light.

Other findings from the correlation analysis revealed that while there was indeed a significant relationship ( $\beta=0.407, p=0.002<p=0.05$ ) between comprehension monitoring and academic performance of primary school pupils in Nakuru West Sub-County, the intervention still could not explain the variations in the dependent variable, that is, academic performance in the multiple regression model. This means that comprehension monitoring as currently practiced in the schools did not translate to academic performance of primary school pupils in Nakuru West SubCounty.

\section{Conclusions}

The study concludes that comprehension had a significant effect on academic performance of primary school pupils in the area $(\beta=0.407, p=0.002<p=0.05)$. Despite the moderate effect comprehension monitoring had on academic performance, it was not being effectively carried out through out all the phases with the teachers mostly concerned about the reading phase of comprehension than the other two phases of pre-reading and post reading. As such most teachers did not adequately prepare their learners well during the pre-reading stage especially with regard to the subject matter and put less emphasis on the post reading stage. Also the post reading phase was less emphasized than the other two phases of reading. Hence, it was evident that the pupils were not adequately prepared by their teachers during comprehension with the focus of teachers being concentrated on the reading phase.

\section{Recommendations}

The study makes the following recommendations based on the findings. From the findings, it was evident that comprehension was poor among the learners and also comprehension monitoring as an intervention was not being carried out effectively. The study, therefore, recommends that the teachers should introduce regular comprehension tests to monitor the students progress in reading compreghension especially at the upper level of primary school.

\section{References}

Anderson, J. R. (2010). Cognitive Psychology and Its Implication (5 $5^{\text {th }}$ Ed.). New York: Worth.

Athiemoolam, L., \& Kibui, A. (2012). An Analysis of Kenyan Learners' Proficiency in English Based on Reading Comprehension and Vocabulary, Journal of NELTA, 17(2), 1-13 Retrieved Nov 2018, from https://www.nepjol.info/index.php/NELTA/article/view/8088

Babbie, E. R. (2015). The practice of social research. Nelson Education.

Chaseling, M., Boyd, W. E., Robson, K., \& Brown, L. (2014). Whatever it takes! Developing professional learning communities in primary school mathematics education. Creative Education, 5(11), 864. Retrieved Jan 2019, from:

https://epubs.scu.edu.au/esm_pubs/2403/ 
INTERNATIONAL JOURNAL OF ACADEMIC RESEARCH IN BUSINESS AND SOCIAL SCIENCES

Vol. 9, No. 11, November, 2019, E-ISSN: 2222-6990 @ 2019 HRMARS

Chou, M. J., \& Cheng, J. C. (2015). Parent-Child Aesthetic Shared Reading with Young Children. Universal Journal of Educational Research, 3(11), 871-876. DOI: 10.13189/ujer.2015.031113

Cimmiyotti, C. B. (2013). Impact of Reading Ability on Academic Performance at the Primary Level. (Master's Theses and Capstone Projects). Dominican University of California. 127. Retrieved from https://scholar.dominican.edu/masters-theses/127

Denton, C. A. (2012). Response to intervention for reading difficulties in the primary grades: Some answers and lingering questions. Journal of learning disabilities, 45(3), 232-243. https://doi.org/10.1177/0022219412442155

Denton, C. A., \& Al Otaiba, S. (2011). Teaching word identification to students with reading difficulties and disabilities. Focus on exceptional children, 2011, 254245149. https://www.ncbi.nlm.nih.gov/pmc/articles/PMC4299759/

Ferrer, E., Shaywitz, B. A., Holahan, J. M., Marchione, K., \& Shaywitz, S. E. (2010). Uncoupling of reading and IQ over time: empirical evidence for a definition of dyslexia. Psychology Science. 21(1), 93-101. https://www.ncbi.n/m.nih.gov/pubmed/20424029

Fletcher, J. M., Lyon, G. R., Fuchs, L. S., \& Barnes, M. A. (2007). Learning disabilities: From identification to intervention. New York: The Guilford Press.

Ganimian, A. J., \& Murnane, R. J. (2016). Improving education in developing countries: lessons from rigorous impact evaluations. Revolutionary Education Research, 1, 1-37. https://psycnet.apa.org/record/2016-36534-003

Giess, S., Rivers, K., Kennedy, K., \& Lombardino, L. (2012). Effects of multisensory phonics-based training on the word recognition and spelling skills of adolescents with reading disabilities. International Journal of Special Education, 27(1), 60-73. https://digitalcommons.chapman.edu/education_articles/69/

Gósy, M., Huntley Bahr, R., Gyarmathy, D., \& Beke, A. (2018). Dichotic listening and sentence repetition performance in children with reading difficulties. Clinical linguistics \& phonetics, 1-17. https://doi.org/10.1080/02699206.2018.1431807

Graesser, A. C., Singer, M. \& Tenebaum, T. (1994). Constructing Inferences during Narrative Text Comprehension. Psychological Review, 101(2), $371-395$. http://dx.doi.org/10.1037/0033-295X.101.3.371

Hall, K. (2013). Effective literacy teaching in the early years of school: a review of evidence. In: Larson, J., March, J. (Eds.), The Sage Handbook of Early Childhood Literacy. Sage Publications Ltd, London, UK. Retrieved Dec 2018, from:sk.sagepub.com/reference/hdbk_earlychildhoodliteracy/n29.xml

Jacobs, K. (2007). Defining Reading Disabilities: Multiple Deficits Behind One Problem. Defining Reading Disabilities, 2. Retrieved Nov 2018, from: https://pdfs.semanticscholar.org/d067/c96e70cd962ca911261472b7dec9078f3c9f.pdf

Jukes, M. C. H., Turner, E. L., Dubeck, M. M., Halliday, K. E., Inyega, H. N., Wolf, S., Zuilkowski, S. S., Brooker, S. J. (2017). Improving literacy instruction in Kenyathrough teacher professional development and text messages support: a cluster randomized trial. 
INTERNATIONAL JOURNAL OF ACADEMIC RESEARCH IN BUSINESS AND SOCIAL SCIENCES

Vol. 9, No. 11, November, 2019, E-ISSN: 2222-6990 @ 2019 HRMARS

Journal of Research in Education Effectiveness, 10 (3), 449-481. Retrieved Nov 2018, from:

https://www.poverty-action.org/.../Wolf\%20Turner\%20Jukes\%20Dubeck_2018_IJED

Karanja, W. (2015). Effects of reading difficulties on academic performance among form three students in public secondary schools, Kiambu County, Kenya. (Masters Thesis), Kenyatta University, Nairobi, Kenya. Retrieved Dec 2018, from:

https://ir-library.ku.ac.ke/handle/123456789/13253

Kintsch, W. (1998). Comprehension a Paradigm of Cognition in Academic. Cambridge, England: Cambridge University Press.

Kintsch, W. \& Rowson, K.A. (2005). Comprehension in M.J. Snowling and Hulme (Eds). The science of Reading: A Handbook. Maldan, M.A: Blackwell

Kinyanjui, M. C. (2009). Reflections on Education in East African Countries. Nairobi: Oxford University Press.

KISE (2018). The National Survey on Children with Disabilities and Special Needs.

Kothari, C.R. (2011). Research Methodology: Methods \& Techniques (2 ${ }^{\text {nd }}$ ed.). New Delhi:K.K. Gupta

Kyle, F., Kujala, J., Richardson, U., Lyytinen, H., \& Goswami, U. (2013). Assessing the effectiveness of two theoretically motivated computer-assisted reading interventions in the United Kingdom: GG rime and GG phoneme. Reading Research Quarterly, 48(1), 61-76. Retrieved Nov 2018, from:openaccess.city.ac.uk/3367/

Lerner, J. (2000). Learning Disabilities; Theories Diagnosis and Teaching Strategies ( $8^{\text {th }}$ ed.). Boston: Houghton Mifflin.

Lyytinen, H., \& Erskine, J. (2016). Early Identification and Prevention of Reading Problems. Learning Disabilities. CEECD / SKC-ECD. Retrieved Dec 2018, from: https://jyx.jyu.fi/handle/123456789/50671?locale-attribute=en

MacGregor, M., \& Price, E. (1999). An Exploration of Aspects of Language Proficiency and Algebra Learning. Journal for Research in Mathematics Education 30(4), 449-467. Retrieved Dec 2018, from:https://www.jstor.org/stable/749709

Marshall, C., \& Rossman, G. B. (2014). Designing qualitative research. Sage publications.

Maxfield, M. G., \& Babbie, E. R. (2014). Research methods for criminal justice and criminology. Cengage Learning.

McEwan, P. J. (2015). Improving learning in primary schools of developing countries: a metaanalysis of randomized experiments. Revolutionary Education Research, 85, 353-394. Retrieved from: https://journals.sagepub.com/doi/abs/10.3102/0034654314553127

McLaughlin, M. J., Speirs, K. E., \& Shenassa, E. D. (2014). Reading disability and adult attained education and income: evidence from a 30-year longitudinal study of a population-based sample. Journal of Learning Disability, 47:374. From:

https://www.ncbi.nlm.nih.gov/pubmed/22983608

Chang, M. S. (2013). Academic Language Knowledge and Comprehension of Science Text for English Language Learners and Fluent English-speaking Students (Doctoral dissertation, University of California, Los Angeles). From: adsabs.harvard.edu/abs/2013PhDT.......105C 
Mol, S. E., \& Bus, A. G. (2011). To read or not to read: a meta-analysis of print exposure from infancy to early adulthood. Psychology Bulletin, 137 (2), 267-296. from: https://www.ncbi.nlm.nih.gov/pubmed/21219054

Mugenda, O., \& Mugenda, A. (2003). Research Methods, Qualitative and Qualitative Approaches. Nairobi: Act Press

Murnane, R. J. (2007). Improving the education of children living in poverty. Future Child, 17:161. Retrieved Jan 2019, from:https://www.ncbi.n/m.nih.gov/pubmed/17902265

Mwanamukubi, L. (2013). Reading difficulties in grade six learners and challenges faced by teachers in teaching reading: A case of Chadiza and Chipata Districts, Zambia. (Unpublished Masters Thesis). The University of Zambia, Lusaka, Zambia. Retrieved from dspace.unza.zm:8080/xmlui/handle/123456789/2715

Nakuru County Education Office (2017). Nakuru County keen on improving education performance. From:

http://nakuru.go.ke/news/nakuru-county-keen-on-improving-education-performance/

Nassiuma, D. K. (2000). Survey sampling: Theory and methods. University of Nairobi press: Nairobi.

Oberholzer, B. (2005). The relationship between reading difficulties and academic performance among a group of foundation phase learners who have been identified as experiencing difficulty withreading, and referred for reading remediation. Department of Psychology. Pietermaritzburg: University of Zululand.

Ojanen, E., Rominus, M., Ahonen, T., Chansa-Kabali, T., February, P., \& Jere-Folotiya, J., (2015). GraphoGame - a catalyst for multi-level promotion of literacy in diverse contexts. Frontiers in Psychology, 6(671), 1-13 Retrieved Jan 2019, from: https://www.ncbi.nlm.nih.gov/pubmed/26113825

Ombra, A. I. (2010). Reading skill predictors of students' performance in mathematics and science. (PhD Dissertation), Notre Dame University, New York. http//www.uad.ac.id/index.php/EduLearn/article/download/3430/pdf_130

Onkoba, M. K. (2014). Correlation between reading comprehension practices and academic performance: A case study of class three pupils in Westlands Sub-County, Kenya. (Unpublished Masters Thesis), University of Nairobi, Nairobi, Kenya. Retrieved Jan 2019, from:

https://www.academia.edu/.../Correlation_between_Reading_Comprehension_level_an

Oso, W. Y., \& Onen D. (2009). A General Guide to Writing Research Proposal and Report A hand Book for Beginning Researchers. Nairobi: Option Press and Publishers.

Oyetunde, T. O., Ojo, G., Korb, K. A., \& Babudoh, G. (2016). Improving Literacy Instructional Practices in Primary Schools in Nigeria: Strategies that Work. Literacy Information and Computer Education Journal, 6(2), 2323-28. Retrieved from

http//www.korbedpsych.com/LinkedFiles/EvaluationReadingSkills.pdf

Piper B., \& Zuilkowski, S. S. (2015). Assessing reading fluency in Kenya: Oral or silent assessment? International Review of Education. Springer. doi 10.1007/s11159-015-9470-4 
INTERNATIONAL JOURNAL OF ACADEMIC RESEARCH IN BUSINESS AND SOCIAL SCIENCES

Vol. 9, No. 11, November, 2019, E-ISSN: 2222-6990 @ 2019 HRMARS

Rahim, P. R. M. A. (2018). Facilitating Reading Comprehension among ESL Learners. Malaysian Journal of ELT Research, 13(1), 30-42. https://www.semanticscholar.org/.../FacilitatingReading-Comprehension-among-ESL

Piper, B., Zuilkowski, S. S., \& Mugenda, A. (2014). Improving reading outcomes in Kenya: firstyear effects of the PRIMR Initiative. International Journal of Education Development, 37, 11-21. https://doi.org/10.1016/j.ijedudev.2014.02.006

Richardson, U., \& Lyytinen, H. (2014). The GraphoGame Method: The Theoretical and Methodological Background of the Technology-Enhanced Learning Environment for Learning to Read. Human Technology: An Interdisciplinary Journal on Humans in ICT Environments,10(1), 39-60. doi:10.17011/ht/urn.201405281859</a

Scanlon, D. M., Anderson, K. L., \& Sweeney, J. M. (2016). Early intervention for reading difficulties: The interactive strategies approach. New York: Guilford Publications.

Sekaran, U., \& Bougie, R. (2016). Research methods for business: A skill building approach. John Wiley \& Sons.

Sigfried, J., \& Fels. (1979). Research on Teaching College Economics: A Survey. Journal of Economics Literature, 17 (2) 923-69. From: https://www.jstor.org/stable/pdf/2723388.pdf

Singh, A., \& Masuku, M. (2012). Understanding and applications of test characteristics and basics inferential statistics in hypothesis testing. European Journal of Applied Sciences, 4(2), 90 7. ijecm.co.uk/wp-content/uploads/2014/11/21131.pdf

Tankersley, K. (2003). The threads of reading: Strategies for literacy development. Alexandria, VA: Association for Supervision and Curriculum Development.

UNESCO. (2014). Teaching and Learning-Achieving Quality for All. Education for All Global Monitoring Report. From: http://unesdoc.unesco.org/images/0022/002256/225660e.pdf

USAID. (2007). An Analysis of USAID Assistance to Basic Education in the Developing World, 1990-2005. Washington D.C.: USAID.

Uwezo. (2010). Are Our Children Learning? Annual Learning Assessment Report. 2010. From: www.uwezo.net/wp-content/uploads/2010/.../Kenya-Report-2011-WebFinalUpdate.pd.

Uwezo. (2011). Are Our Children Learning? Annual Learning Assessment Report, 2011. From: www.uwezo.net/wp-content/uploads/2012/.../UG_2011_AnnualAssessmentReport.pdf

Whitney, P., Budd, D., Bramucci, R. S., \& Crane, R. S. (1995). A Reconsideration of Top Down Processes in Comprehension. Discover Processes, 23(3), 135- 166. https://doi.org/10.1080/01638539509544935

Wolf, M., \& Katzir-Cohen, T. (2001). Reading fluency and its intervention. Scientific Studies of Reading, 5, 211-239. http://dx.doi.org/10.1207/S1532799XSSR0503_2

Yamashita, T., \& Hayashi, T. (2014). Effects of reading difficulties on scholastic self-evaluation and mental health in elementary school children. PubMed, 46(3), 221-225. From: https://www.ncbi.nlm.nih.gov/pubmed/24902344 